\title{
PURIFICATION AND PARTIAL CHARACTERIZATION OF MANGANESE PEROXIDASE FROM Bacillus pumilus AND Paenibacillus sp.
}

\section{${ }^{1}$ Patrícia Lopes de Oliveira*; ${ }^{1}$ Marta Cristina Teixeira Duarte; ${ }^{1}$ Alexandre Nunes Ponezi, ${ }^{2}$ Lúcia Regina Durrant}

${ }^{1}$ Divisão de Microbiologia, Centro Pluridisciplinar de Pesquisas Químicas, Biológicas e Agrícolas, Universidade Estadual de Campinas, Campinas, SP, Brasil. ${ }^{2}$ Laboratório de Sistemática e Fisiologia Microbiana, Faculdade de Engenharia de Alimentos, Universidade Estadual de Campinas, Campinas, SP, Brasil.

Submitted: January 01, 2009; Returned to authors for corrections: March 03, 2009; Approved: May 15, 2009.

\begin{abstract}
The production of manganese peroxidase (MnP) from Bacillus pumilus and Paenibacillus sp. was studied under absence and presence of the inducers indulin AT, guayacol, veratryl alcohol, lignosulfonic acid and lignosulfonic acid desulfonated. Indulin AT increased the activity of B. pumilus $\mathrm{MnP}$ up to $31.66 \mathrm{U} / \mathrm{L}$ after $8 \mathrm{~h}$, but no improve was observed for Paenibacillus sp., which reached maximum activity (12.22 $\mathrm{U} / \mathrm{L}$ ) after $20 \mathrm{~h}$. Both MnPs produced by these microorganisms were purified in phenyl sepharose resin and the proteins from crude extracts were eluted in two fractions. However, only the first fraction of each extract exhibited MnP activities. Tests in different $\mathrm{pH}$ and temperature values, from $\mathrm{pH} 5.0$ to $\mathrm{pH} 10.0$ and $30{ }^{\circ} \mathrm{C}$ to $60^{\circ} \mathrm{C}$, respectively, were carried out with the purified MnP. The maximum activity reached for $B$. pumilus and Paenibacillus sp. MnPs were 4.3 U/L at pH 8.0 and $25^{\circ} \mathrm{C}$ and $11.74 \mathrm{U} / \mathrm{L}$ at $\mathrm{pH} 9.0$ and $35{ }^{\circ} \mathrm{C}$, respectively. The molar masses determined by SDS-PAGE gel eletrophoresis were $25 \mathrm{kDa}$ and $40 \mathrm{kDa}$, respectively, for the purified enzyme from B. pumilus and Paenibacillus sp.
\end{abstract}

Key words: Bacillus pumilus; Paenibacillus sp.; Manganese peroxidase; Purification; Characterization.

\section{INTRODUCTION}

Plant cell walls have lignin in their structure as the most abundant component. Lignin is an aromatic and heterogeneous constituent that ensures strength and resistance towards microbial attack. White-rot basidiomycetes are the most common organisms known to efficiently degrade and mineralize lignin into $\mathrm{CO}_{2}$ and $\mathrm{H}_{2} \mathrm{O}$, due to extracellular enzymes involved in lignin degradation, particularly the ligninase complex, formed by laccase, lignin peroxidase and manganese peroxidase $(10,11)$. Rarely these three enzymes are present in the same organism, and different combinations of them can operate. The ligninase complex is frequently produced during secondary metabolism but different species have particular responces to nutrients $(19,25)$.

Due to the important degradative potential of manganese peroxidase $(\mathrm{MnP})$, there is a general interest in producing the enzyme biotechnologically. Manganese peroxidase, a glycosylated heme-containing enzyme, have been used besides biodegradation of lignin (13), in the biodegradation

*Corresponding Author. Mailing address: Divisão de Microbiologia - Centro Pluridisciplinar de Pesquisas Químicas, Biológicas e Agrícolas, CPQBAUNICAMP, Caixa Postal 6171, CEP 13083-080, Campinas, SP, Brasil.; Email: patricia_lopes13@yahoo.com.br 
of polycyclic aromatic hydrocarbons $(\mathrm{PAH})(24,27)$, humic acids (28), synthetic dyes (12), and polychlorinated biphenyls (PCB) (2). MnP oxidizes $\mathrm{Mn}^{2+}$ to $\mathrm{Mn}^{3+}$ in an $\mathrm{H}_{2} \mathrm{O}_{2}$-dependent reaction and $\mathrm{Mn}^{3+}$ is stabilized by chelating dicarboxylic acids (8).

The optimum $\mathrm{pH}$ of almost all ligninolytic enzymes, including $\mathrm{MnP}$, reported to date lies in the acidic range. However some industry activities, such as pulping and bleaching are mainly performed under highly alkaline conditions and the waste generated is also alkaline. Ligninolytic enzymes having acidic optimum $\mathrm{pH}$ values cannot be used under alkaline conditions (16).

Few reports on bacterial $\mathrm{MnP}$ are found in the literature. Two bacteria, B. pumilus, isolated from wood decomposition material by Duarte et al. (6) and Paenibacillus sp. isolated from paper mill effluent (22) were able to produce $\mathrm{MnP}$ in alkaline conditions. These enzymes were able to remove the color from paper mill effluent (23). In this study, we report on the purification and partial characterization of $\mathrm{MnP}$ from B. pumilus and Paenibacillus sp.

\section{MATERIALS AND METHODS}

\section{Microorganisms}

Bacillus pumilus CBMAI 0008 was isolated from wood decomposition material by Duarte et al. (6) and was maintained in a culture medium containing birchwood xylan (20).

Paenibacillus sp. CBMAI 868 was isolated from paper industry effluent, in a media containing $1 \%$ birchwood xylan (Sigma); $0.1 \%\left(\mathrm{NH}_{4}\right)_{2} \mathrm{SO}_{4} ; 50 \%$ paper mill effluent; and $2 \%$ agar-agar. After sterilization, nistatin $(0,044 \mathrm{mg} / \mathrm{mL})$ was added as an antifungal control. An aliquot of $0.3 \mathrm{~mL}$ from paper mill effluent was used to sow the surface medium in Petri plates. After incubation $\left(37{ }^{\circ} \mathrm{C}, 48 \mathrm{~h}\right)$, the ability of colonies to grow and produce clear haloes of decolorization on the medium surface was verified. The colony that provided the greater clear haloe was purified and identified at Microbial Resources Divison - CPQBA/UNICAMP.
The subsequent assays were carried out at $45{ }^{\circ} \mathrm{C}$ for both bacteria, once this temperature is close to that used in several industrial processes.

\section{Inocula preparation}

The isolates were individually transferred to $125 \mathrm{~mL}$ Erlenmeyer flasks, containing $12.5 \mathrm{~mL}$ of the liquid media (20), and incubated at $45{ }^{\circ} \mathrm{C}$ in a shaker $(250 \mathrm{rpm})$ for $20 \mathrm{~h}$. The culture was centrifuged in aseptic conditions and the cells were ressuspended in $40 \mathrm{~mL}$ of the media. Further steps of $\mathrm{MnP}$ production were carried out using inoculum at $8 \%$ $(\mathrm{v} / \mathrm{v})$.

\section{Effect of inducers on the MnP production}

For cinetic studies, inocula were prepared as described above and the fermentation was carried out in $250 \mathrm{~mL}$ Erlenmeyer flasks, containing $50 \mathrm{~mL}$ of the liquid media, and incubated at $45{ }^{\circ} \mathrm{C}$ in a shaker $(250 \mathrm{rpm})$ during $32 \mathrm{~h}$. At regular periods, samples were collected for $\mathrm{MnP}$ activity measurement. MnP production was also studied in the presence of veratryl alcohol, industrial lignin (indulin AT), guayacol, lignosulfonic acid and lignosulfonic acid desulfonated at $0.1 \%(\mathrm{w} / \mathrm{v})$ at the same conditions. The fermented media was centrifuged for $15 \mathrm{~min}$ at $12000 \mathrm{x} \mathrm{g}$ for the activity assays.

\section{Enzyme activity assay}

Manganese peroxidase activity was assayed spectrophotometrically according to Kuwahara (17). The reaction mixture contained $0.1 \mathrm{~mL}$ of $0.25 \mathrm{M}$ sodium lactate, $0.05 \mathrm{~mL}$ of $2 \mathrm{mM} \mathrm{MnSO} 4,0.2 \mathrm{~mL}$ of $0.5 \%$ serum albumin bovine, $0.1 \mathrm{~mL}$ of $0.1 \%$ phenol red, $0.5 \mathrm{~mL}$ enzyme and 0.05 $\mathrm{mL}$ of $2 \mathrm{mM} \mathrm{H}_{2} \mathrm{O}_{2}$ in $0.2 \mathrm{M}$ sodim phosphate buffer ( $\mathrm{pH} 8.0$ ). The mixture was left at room temperature for $5 \mathrm{~min}$ and the reaction was ended with $0.04 \mathrm{~mL} \mathrm{NaOH} 2 \mathrm{~N}$. The absorbance was read at $610 \mathrm{~nm}$ and the activity expressed in U/L. One activity unit was defined as amount of enzyme necessary to oxidize $1 \mu \mathrm{mol}$ of substrate per minute. 


\section{Proteins measurement}

Protein concentration was measured by the Bradford method (3). Bovin serum albumin was used as a standard. The results were used to calculate specific activity.

\section{Culture conditions for crude extracts production aim} purification and characterization

The culture conditions for crude extracts production aim purification and characterization were determined after inducers studies. The bacteria were cultured as described above for inoculum production and subsequently inoculated in the medium containing xylan (20) enriched with indulin AT (B. pumilus) or without inducer (Paenibacillus sp.), and incubated at $45{ }^{\circ} \mathrm{C}$ in a shaker $(250 \mathrm{rpm})$ for $8 \mathrm{~h}$ or $20 \mathrm{~h}$, respectively. The cultures were centrifuged during $15 \mathrm{~min}$ at $12000 \mathrm{x} g$ prior the purification assays.

\section{MnP purification and partial characterization}

All purification procedures were done at room temperature. The enzyme activity and protein concentrations were determined in all steps. The supernatant obtained from the crude broth was filtered (Whatman $0.45 \mu \mathrm{m}$ ) and futher concentrated in a Pellicon ${ }^{\mathrm{TM}}$ ultrafiltration system using 10 $\mathrm{kDa}$ Biomax $10^{\mathrm{TM}}$ membrane. The concentrated solution was loaded to a Pharmacia KX-26 40/26 column packed with Phenyl Sepharose hydrophobic interaction chromatography (HIC) resin coupled to a Pharmacia FPLC, previously equilibrated with $1.7 \mathrm{M}\left(\mathrm{NH}_{4}\right)_{2} \mathrm{SO}_{4}$ (9). The flow rate was 3 $\mathrm{mL} / \mathrm{min}$ and proteins were eluted in a linear $\left(\mathrm{NH}_{4}\right)_{2} \mathrm{SO}_{4}$ gradient from 1.7 to $0 \mathrm{M}$ in sodium phosphate buffer, $\mathrm{pH} 7.0$, $50 \mathrm{mM}$. The peaks containing $\mathrm{MnP}$ activity were pooled, concentrated and dialyzed against the same buffer. The HICseparated $\mathrm{MnP}$ was further loaded to a Pharmacia KX-16 16/2 column packed with Q-Sepharose anion exchange chromatography resin coupled to a Pharmacia FPLC, previously equilibrated with sodium phosphate $50 \mathrm{mM}$. The flow rate was $2 \mathrm{~mL} / \mathrm{min}$ and proteins were eluted with sodium phosphate $50 \mathrm{mM}$ in a linear $\mathrm{NaCl}$-gradient from 0 to
$1 \mathrm{M}, \mathrm{pH}$ 7.0. The peaks were all collected in a Red Frak ${ }^{\mathrm{TM}}$ (Pharmacia) system, monitored at $280 \mathrm{~nm}$.

\section{Electrophoresis - SDS PAGE}

Purity and apparent molecular weights of the peaks were examined by SDS-polyacrylamide gel electrophoresis (SDSPAGE) as described by Laemmli (18) using a Mini-Protean II system (Biorad). Molecular weight markers (Promega) were included in 10\% gels, followed by Comassie Blue R-250 staining.

\section{Effect of $\mathrm{pH}$ and temperature on MnP activity}

The effect of $\mathrm{pH}$ on purified $\mathrm{MnP}$ activity from $B$. pumilus and Paenibacillus sp. was studied in the following buffers $(200 \mathrm{mM})$ : citrate phosphate, $\mathrm{pH} 5.0$ and $\mathrm{pH}$ 6.0; sodium phosphate, $\mathrm{pH} 7.0$ and $\mathrm{pH}$ 8.0; and glycine- $\mathrm{NaOH}$, $\mathrm{pH} 9.0$ and $\mathrm{pH}$ 10.0. The effect of temperature was determined in range from $25{ }^{\circ} \mathrm{C}$ to $60{ }^{\circ} \mathrm{C}$ with $5{ }^{\circ} \mathrm{C}$ intervals and the incubation was according to Kuwahara et al. method (17).

\section{RESULTS AND DISCUSSION}

\section{Effect of inducers on the production of $\mathrm{MnP}$}

The production of $\mathrm{MnP}$ was determined in the crude extract of B. pumilus and Paenibacillus sp., in the absence and presence of inducers. The maximum activity reached for the $B$. pumilus $\mathrm{MnP}$ without inducers was $6.41 \mathrm{U} / \mathrm{L}$ after $16 \mathrm{~h}$ (Figure 1-A). When the inducers were added in the culture medium, the activity increased to $31.66 \mathrm{U} / \mathrm{L}$ in the presence of indulin AT after $8 \mathrm{~h}$ (Figure 1-B), followed by lignosulfonic acid (15.6 U/L) and lignosulfonic acid desulfonated (8.6 U/L) after $6 \mathrm{~h}$ (Figures 1-D and 1-E, respectively). The maximum $\mathrm{MnP}$ production by Paenibacillus sp. was $13.76 \mathrm{U} / \mathrm{L}$ in the presence of veratryl alcohol after $28 \mathrm{~h}$ (Figure 1-C). The addition of lignosulfonic acid desulfonated resulted in a maximum activity of 12.78 $\mathrm{U} / \mathrm{L}$ at the same time (Figure 1-D), while maximum activity in the presence of guayacol was $12.20 \mathrm{U} / \mathrm{L}$ after $20 \mathrm{~h}$ (Figure 
1-F). These results did not show improve in the Paenibacillus sp. $\mathrm{MnP}$ activity since the activity without inducers was 12.33 U/L after $20 \mathrm{~h}$ (Figure 1-A). No data was found in the literature about the use of inducers in the $\mathrm{MnP}$ production from bacteria. The use of Polyfon $\mathrm{H}$ as inducer in the $\mathrm{MnP}$ production by the fungus Irpex flavus allowed reaching 0.08
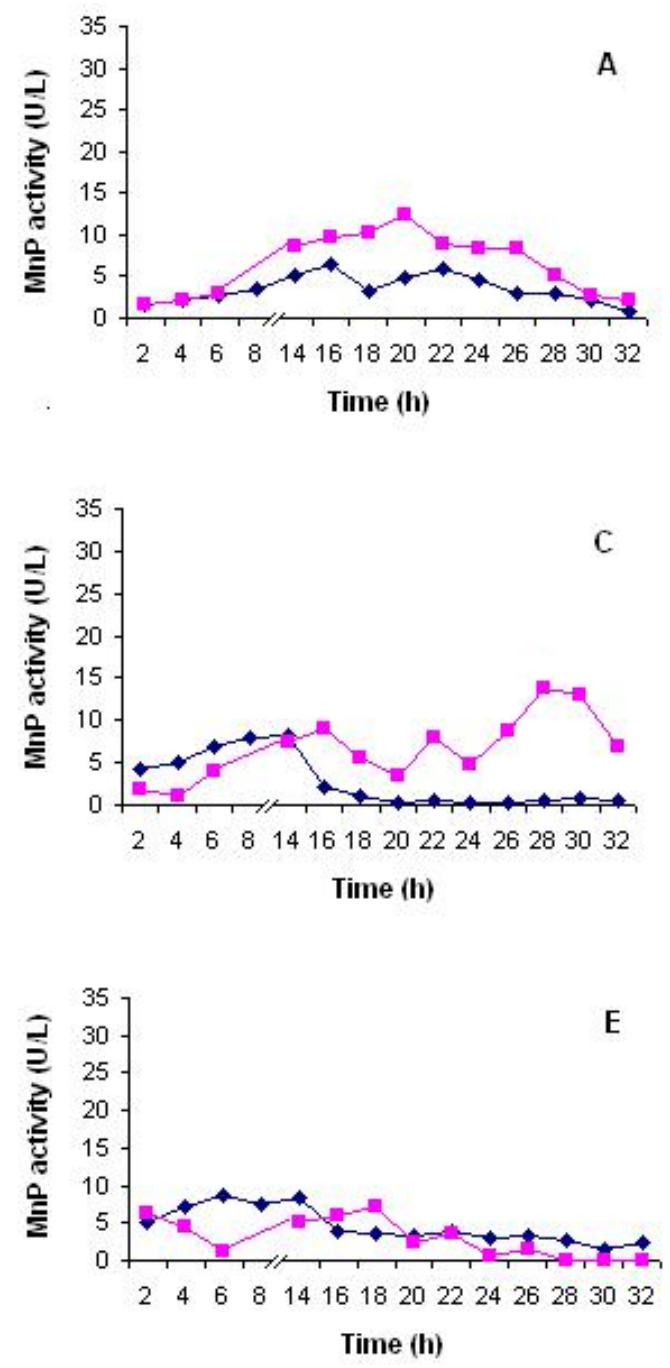

$\mathrm{U} / \mathrm{mL}$. Inducers absence in the media was the best conditions for $\mathrm{MnP}$ production by Dichomitus squalens $(0.29 \mathrm{U} / \mathrm{mL})$ and Polyporus sanguineus $(0.43 \mathrm{U} / \mathrm{mL})(7)$. Further study revelead that indulin AT, Polyfon $\mathrm{H}$, Reax 80, Orzan S, veratryl alcohol and guayacol did not increase MnP activity by Phlebia floridensis, a white-rot fungus (1).
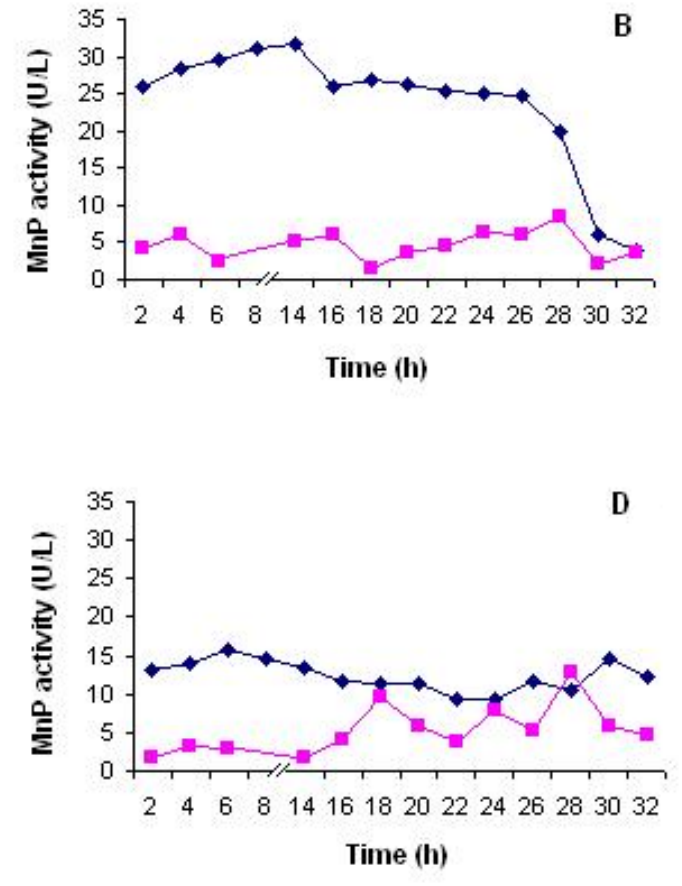

Figure 1. MnP production by B. pumilus CBMAI $0008(-\bullet)$ ) and Paenibacillus sp. CBMAI $868(--)$. A - no inducers; B - indulin AT; C - veratryl alcohol; D - dissulf lignin acid; E - lignin acid and F - guayacol. 


\section{Enyme purification}

The crude extract produced by B. pumilus and Paenibacillus sp. was first taken through the hydrophobic interaction resin (phenyl sepharose) obtaining two peaks as shown in Figures 2-A and 2-B. Subsequently, the eluted peaks were submitted to ultrafiltration and further purification in Q-Sepharose anion exchange chromatography resin, confirming the presence of only one proteic fraction. In all purification steps, MnP activity and total proteins were determined. A summary of the purification steps is shown in Table 1.
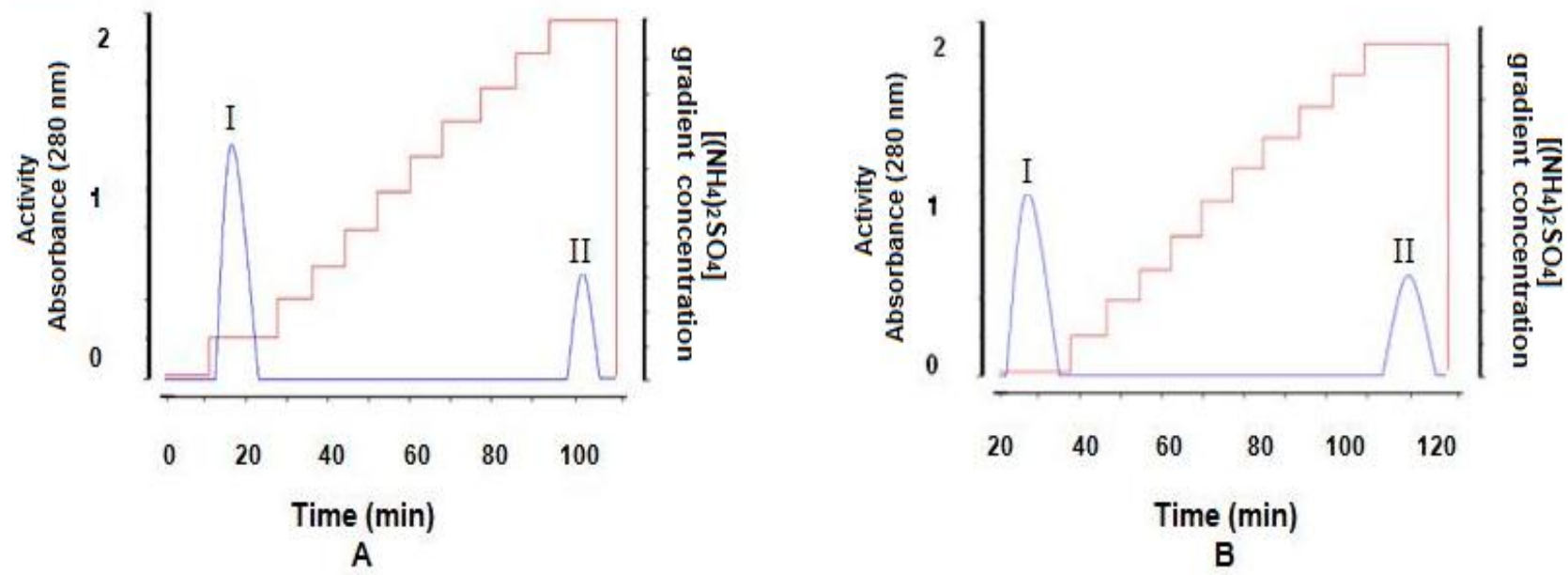

Figure 2. FPLC chromatogram in a Fenil Sepharose hydrophobic interaction resin. A - B. pumilus CBMAI 0008 MnP elution characterized in peak I. B - Paenibacillus sp. CBMAI $868 \mathrm{MnP}$ elution characterized in peak I. Activity ( - ) and gradient concentration $(-)$.

Table 1. Purification steps of MnP from B. pumilus CBMAI 0008 and Paenibacillus sp. CBMAI 868.

\begin{tabular}{lcccccc}
\hline Purification step & $\begin{array}{c}\text { Total } \\
\text { volume } \\
(\mathbf{m L})\end{array}$ & $\begin{array}{c}\text { MnP } \\
\text { activity } \\
\text { (U/L) }\end{array}$ & $\begin{array}{c}\text { Total } \\
\text { protein } \\
\text { (mg/mL) }\end{array}$ & $\begin{array}{c}\text { Specific } \\
\text { activity } \\
\text { (U/mg) }\end{array}$ & $\begin{array}{c}\text { Yield } \\
\mathbf{( \% )}\end{array}$ & Fold \\
\hline \multicolumn{7}{c}{ B. pumilus } \\
Fenil Sepharose & 140 & 0.43 & 0.080 & 5.37 & 100.00 & 1.00 \\
Ultraf./Dial. & 14 & 4.20 & 0.138 & 30.39 & 976.74 & 5.66 \\
Q-Sepharose & 80 & 0.38 & 0.013 & 29.23 & 88.37 & 5.44 \\
Ultraf./Dial. & 8 & 3.45 & 0.110 & 31.36 & 802.33 & 5.84 \\
& & & & & & \\
Fenil Sepharose & 110 & 0.35 & 0.053 & 6.60 & 100.00 & 1.00 \\
Ultraf./Dial. & 11 & 3.20 & 0.317 & 10.09 & 914.29 & 1.53 \\
Q-Sepharose & 70 & 0.28 & 0.044 & 6.36 & 80.00 & 0.96 \\
Ultraf./Dial. & 7 & 2.40 & 0.284 & 8.45 & 685.71 & 1.28 \\
\hline
\end{tabular}




\section{Electrophoresis - SDS PAGE}

The purified MnP from B. pumilus and Paenibacillus sp. appeared as single bands on 10\% SDS-PAGE and presented molecular weights of $25 \mathrm{kDa}$ and $40 \mathrm{kDa}$, respectively (Figure 3). MnP-PGY and MnP-GY produced by fungus Pleorotus ostreatus (15), and a purified MnP from Trametes versicolor (4) revelead molecular weights of $42 \mathrm{kDa}$ close to the molecular weight found for Paenibacillus sp. in the present study. Also Hoshino et al. (14) verified a similar molecular weight of $40 \mathrm{kDa}$ for $\mathrm{MnP}$ produced by fungus Lenzites betulinus. According to this study, the purified MnP from B. pumilus showed inferior molecular weights comparing to those produced by fungus reported in the literature.

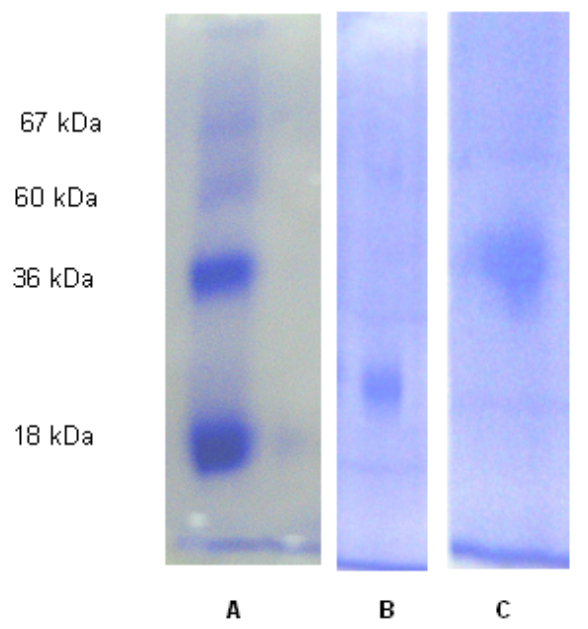

Figure 3. SDS electrophoresis: A - molecular weight standards; B - purified MnP from B. pumilus CBMAI 0008; C - purified MnP from Paenibacillus sp. CBMAI 868. Coomassie Brilliant Blue staining.

\section{Effect of pH and temperature on MnP activity}

The results of enzymatic activity in different $\mathrm{pH}$ and temperature values for purified $\mathrm{MnP}$ from B. pumilus and Paenibacillus sp. are shown in Figures 4-A and 4-B. The activity of B. pumilus MnP increased according to $\mathrm{pH}$ from
5.0 to 8.0 , where occurred the maximum activity $(4.3 \mathrm{U} / \mathrm{L})$, and decreased at superior $\mathrm{pH}$ values (Figure 4-A). Optimum activity for Paenibacillus sp. was observed at pH 9.0 (5.65 $\mathrm{U} / \mathrm{L})$. MnP produced by this bacteria showed greater stability in different $\mathrm{pH}$ values than $\mathrm{MnP}$ produced by B. pumilus, since the lowest activity was at $\mathrm{pH} 6.0$ (3.56 U/L) (Figure 4A). Since the isolation conditions of these microorganisms were carried out in alkaline media, these results confirmed the maximum activities of purified enzymes in these conditions. Tests aiming the determination of optimum temperature values were done at best $\mathrm{pH}$ conditions for both microorganisms. Higher $\mathrm{MnP}$ activity occurred at $25{ }^{\circ} \mathrm{C}$ for B. pumilus (4.3 U/L) and $35{ }^{\circ} \mathrm{C}$ for Paenibacillus sp.(11.74 $\mathrm{U} / \mathrm{L}$ ), (Figure 4-B). MnP activity was not detected at $55^{\circ} \mathrm{C}$ and above (Figure 4-B).

The MnP optimum temperature is variable according to microorganism, as verified in previous studies. Purified MnP from Aspergillus terreus LD-1 showed maximum activity at $37{ }^{\circ} \mathrm{C}$ (16), while the optimum temperature for the enzymes produced by Dichomitus squalens, Irpex flavus and Polyporus sanguineus was $30^{\circ} \mathrm{C}$. In these cases, the enzyme was not detectable at $35{ }^{\circ} \mathrm{C}$, except for MnP from Polyporus sanguineus (7). In the present study, the optimum temperature for purified $\mathrm{MnP}$ from $B$. pumilus and Paenibacillus sp. is the same verified, respectively, for Phebia floridensis (1) and Schizophyllum sp. F17 (5).

We concluded that MnP activity obtained from the crude extract from B. pumilus $(31.66 \mathrm{U} / \mathrm{L})$ was almost three times above that found for Paenibacillus sp. (12.33 U/L).

Recent researches indicate multiples biotechnological applications for fungi MnP. A few mentions on bacterial $\mathrm{MnP}$ are found in the literature. A summary on MnP fungi production comparing with the results obtained in the present study is shown in Table 2. The data show that some fungi spend a longer time (around 8 days) for enzymes production than observed for the bacteria studied in the present work. Therefore, this suggests that may be possible to reach the same activities if we cultured the bacteria during the same period. 
Oliveira, P.L. et al.

In this study, we chose the alkaline effluent from paper industry to cultivate and isolate microorganisms which could grow and secretes useful alkaline lignin-degrading enzymes. Thus, we have purified two alkaline MnPs, respectively from B. pumilus and Paenibacillus sp., and we believe that this is the first report on the bacterial ligninolytic enzymes.
Subsequent tests carried out aimed the color removal from paper mill effluent showed a decrease in the compounds responsible for the colour and confirmed that the compounds present in the paper effluent were depolymerized during the treatment (23), indicating an important application area for these enzymes.
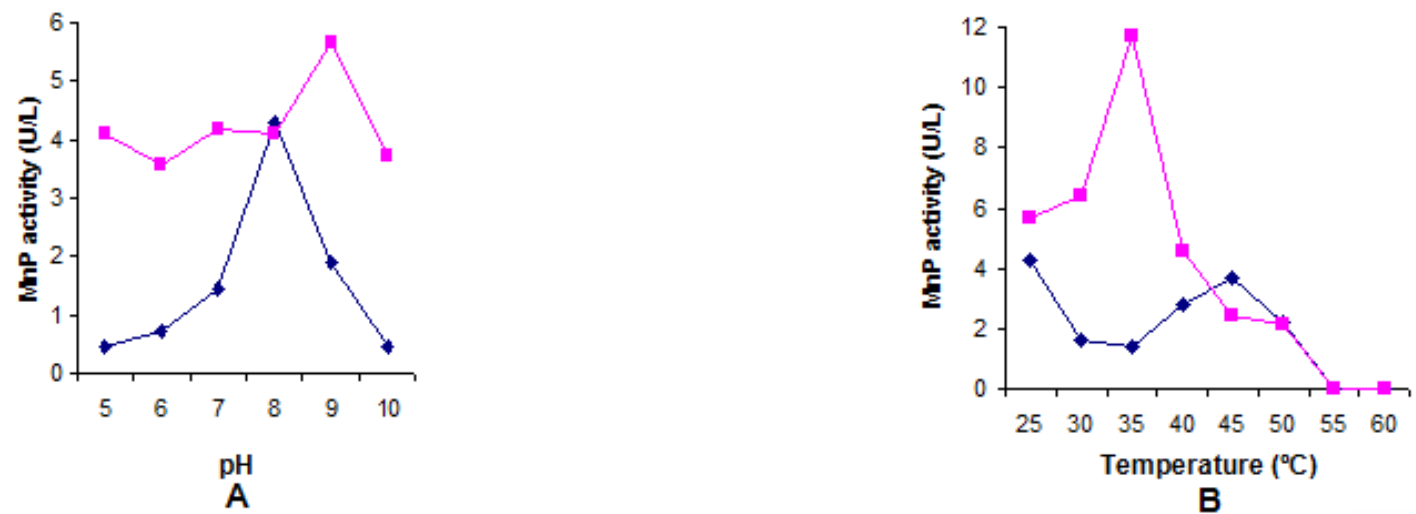

Figure 4. MnP activity from B. pumilus CBMAI $0008(--)$ ) and Paenibacillus sp. CBMAI $868(-1-)$. A - Different pH values, buffers (0.2M): citrate phosphate, $\mathrm{pH} 5.0$ and $\mathrm{pH} 6.0$; sodium phosphate, $\mathrm{pH} 7.0$ and $\mathrm{pH} 8.0$; glycine- $\mathrm{NaOH}$, $\mathrm{pH} \quad 9.0$ and $\mathrm{pH}$ 10.0. B - Different temperature values: B. pumilus, at $\mathrm{pH} 8.0$ - sodium phosphate buffer $0.2 \mathrm{M}$ and Paenibacillus sp., at $\mathrm{pH} 9.0$

- glycine $\mathrm{NaOH}$ buffer $0.2 \mathrm{M}$.

Table 2. MnP activity found in the literature from different microorganisms.

\begin{tabular}{|c|c|c|c|}
\hline Microorganisms & Culture and enzyme production conditions & $\begin{array}{c}\text { Activity } \\
\text { (U/L) }\end{array}$ & References \\
\hline Dichomitus squalens & Malt extract broth, $\mathrm{pH} 5.5$ at $25^{\circ} \mathrm{C}$, after 8 days & 290 & \\
\hline Irpex flavus & Mineral salts broth (MSB) with rice straw, pH 5.5 at $25^{\circ} \mathrm{C}$, after 8 days & 340 & \\
\hline Polyporus sanguineus & Malt extract broth, pH 5.5 at $25^{\circ} \mathrm{C}$, after 8 days & 430 & 7 \\
\hline Pleurotus ostreatus & Yeast extract medium, peptone/glucose, $\mathrm{pH} 7.5$ at $28^{\circ} \mathrm{C}$, after 8 days & 740 & 15 \\
\hline Phlebia floridensis & N-limited MSB broth, $\mathrm{pH} 4.5$ at $25^{\circ} \mathrm{C}$, after 4 days & 60 & 1 \\
\hline Ganoderma sp. & Wheat bran, yeast extract, glucose and ammonium chloride, at $30^{\circ} \mathrm{C}$, after 7 days & 7.8 & 26 \\
\hline Trametes versicolor & Glucose, $\mathrm{pH} 6.0$ at $25^{\circ} \mathrm{C}$, after 8 days & 44 & 21 \\
\hline Bacillus pumilus & Xylan medium with indulin AT, pH 9.0 at $45^{\circ} \mathrm{C}$, after $8 \mathrm{~h}$ & 31.66 & \\
\hline Bacillus pumilus & Purified $\mathrm{MnP}, \mathrm{pH} 8.0$ at $25^{\circ} \mathrm{C}$ & 4.3 & \\
\hline Paenibacillus sp. & Xylan medium, $\mathrm{pH} 9.0$ at $45^{\circ} \mathrm{C}$, after $20 \mathrm{~h}$ & 12.33 & $\begin{array}{c}\text { PRESENT } \\
\text { STUDY }\end{array}$ \\
\hline Paenibacillus sp. & Purified $\mathrm{MnP}, \mathrm{pH} 9.0$ at $35^{\circ} \mathrm{C}$ & 11.74 & \\
\hline
\end{tabular}




\section{ACKNOWLEDGMENTS}

The first author is thankful to CNPq scholarship.

\section{REFERENCES}

1. Arora, D.S.; Gill, P.K. (2005). Production of ligninolytic enzymes by Phlebia floridensis. W. J. Microbiol. Biotechnol. 21, 1021-1028.

2. Beaudette, L.E.; Davies, S.; Fedorak, P.M.; Ward, O.P.; Pickard, M.A. (1998). Comparison of biodegradation and mineralization as methods for measuring loss of selected polycholorinated biphenyl congeners in cultures of four white rot fungi. Appl. Environ. Microbiol. 64, 20202025.

3. Bradford, M.M. (1976). A rapid and sensitive method for quantification of microgram quantities of protein utilizing the principle of protein dye binding. Anal. Biochem. 72, 248-254.

4. Champagne, P.P.; Ramsay, J.A. (2005). Contribution of manganese peroxidase and laccase to dye decoloration by Trametes versicolor. Appl. Microbiol. Biotechnol. 69, 276-285.

5. Cheng, X.; Jia, R.; Li, P.; Tu, S.; Zhu, Q.; Tang, W.; Li, X. (2007). Purification of a new manganese peroxidase of the white-rot fungus Schizophyllum sp. F17, and decolorization of azo dyes by the enzyme. Enz. Microb. Technol. 41 (3), 258-264.

6. Duarte, M.C.T.; Portugal, E.P.; Ponezi, A.N.; Bim, M.A.; Tagliari, C.V.; Franco, T.T. (1997). Production and purification of alkaline xylanases. Bioresour. Technol. 68, 49-53.

7. Gill, P.K.; Arora, D.S. (2003). Effect of culture conditions on manganese peroxidase production and activity by some white rot fungi. J. Indust. Microbiol. Biotechnol. 30 (1), 28-33.

8. Gold, M.H.; Youngs, H.L.; Sollewijn Gelpke, M.D. (2000). Manganese peroxidase. In: Sigel, A.; Sigel, H.(eds). Metal ions in biological systems. Marcel Dekker, New York, USA, p.559-586.

9. Hakala, T.K.; Lundell, T.; Galkin, S.; Maijala, P.; Kalkkinen, N.; Hatakka, A. (2005). Manganese peroxidases, laccases and oxalic acid from the selective white-rot fungus Physisporinus rivulosus grown on spruce wood chips. Enz. Microb. Technol. 36, 461-468.

10. Hatakka, A. (2001). Biodegradation of lignin. In: Hofrichter, M., Steinbuchel A.(eds). Biopolymers, vol. 1, Lignin, humic substances and coal. Wiley-VCH, Weinheim, Germany, p.129-180.

11. Hatakka, A. (1994). Lignin-modifying enzymes from selected white rot fungi: production and role in lignin degradation. FEMS Microbial Rev. $13,125-135$.

12. Heinfling, A.; Martinez, M.J.; Martinez, A.T.; Bergbauer, M.; Szewzyk, U. (1998). Purification and characterization of peroxidases from the dye-decolorizing fungus Bjerkandera adusta. FEMS Microbiol Lett. 165, 43-50.
13. Hilden, L.; Johansson, G.; Pettersson, G.; Li, J.; Ljungquist, P.; Henrikson, G. (2000). Do the extracellular enzymes cellobiose dehydrogenase and manganese peroxidase form a pathway in lignin biodegradation? FEBS Lett. 477, 79-83.

14. Hoshino, F.; Kajino, T.; Sugiyama, H.; Asami, O.; Takahashi, H. (2002). Thermally stable and hydrogen peroxide tolerant manganese peroxidase (MnP) from Lenzites betulinus. FEBS Letters. 530, 249-252.

15. Kamitsuji, H.; Honda, Y.; Watanabe, T.; Kuwahara, M. (2004) Production and induction of manganese peroxidase isozymas in a white-rot fungus Pleurotus ostreatus. Appl. Microbiol. Biotechnol. 65, 287-294.

16. Kanayama, N.; Suzuki, T.; Kawai, K. (2002). Purification and characterization of an alkaline manganese peroxidase from Aspergillus terreus LD-1. J. of Biosci. Bioeng. 93(4), 405-410.

17. Kuwahara, M.; Glenn, J.K.; Morgan, M.A.; Gold, M.H. (1984). Separation and characterization of two extracellular $\mathrm{H}_{2} \mathrm{O}_{2}$ dependent oxidases from lignolytic cultures of Phaerochaete chrysosporium. FEBS Letter. 169, 247-250.

18. Laemmli, U.K. (1970). Cleavage of structural proteins during the assembly of head of bacteriophage T4. Nature. 227, 680-685.

19. Li, D.; Alic, M.; Gold, M.H. (1994). Nitrogen regulation of lignin peroxidase gene transcription. Appl. Environ. Microbiol. 60, $3447-$ 3449

20. Mandels, N.; Stenberg, D. (1976). Recent advances in cellulase technology. J. Fermentation Technol. 54, 267-286.

21. Mikiashvili, N.; Elisashbili, V.; Wasser, S.; Nevo, E. (2005). Carbon and nitrogen sources influence the ligninolytic enzyme activity of Trametes versicolor. Biotech. Lett. 27, 955-959.

22. Oliveira, P.L. (2008). Purificação e caracterização bioquímica de manganês peroxidase de Bacillus pumilus e Paenibacillus sp. e sua atuação na remoção da cor do efluente da indústria papeleira. São Paulo, Brasil, 69p. (M.Sc. Dissertation. Faculdade de Engenharia de Alimentos. UNICAMP)

23. Oliveira, P.L.; Duarte, M.C.T.; Ponezi, A.N.; Durrant, L.R. (2009). Use of Bacillus pumilus CBMAI 0008 and Paenibacillus sp. 868 for colour removal from paper mill effluent. Brazil. J. Microbiol. 40, 354-357.

24. Pickard, M.A.; Roman, R.; Tinoco, R.; Vazquez-Duhalt, R. (1999) Polycyclic aromatic hydrocarbon metabolism by white rot fungi and oxidation by Coriolopsis gallica UAMH 8260 laccase. Appl. Environ. Microbiol. 65, 3805-3809.

25. Reddy, C.A.; D’Souza, T.M. (1994). Physiology and molecular biology of the lignin peroxidases of Phanerochaete chrysosporium. FEMS Microbial Rev. 13, 137-152.

26. Silva, C.M.M.S.; Melo, I.S.; Oliveira, P.R. (2005). Ligninolytic enzyme production by Ganoderma spp. Enz. Microbial Technol. 37, 324-329.

27. Wariishi, H.; Valli, K.; Gold, M.H. (1992). Manganese (II) oxidation by manganese peroxidase from the basidiomycete Phanerochaete chrysosporium. J. Biol. Chem. 267, 23688-23695. 
Oliveira, P.L. et al.

28. Ziegenhagen, D.; Hofrichter, M. (1998). Degradation of humic acids by manganese peroxidase from the white-rot fungus Clitocybula dusenii. $J$. Basic Microbiol. 38, 289-299. 